\title{
Antigenic Identity between the Soluble Glycoprotein of Milk Fat Globule Membrane and a Heat-stable Protein Fraction of Whey
}

\author{
Choemon KanNo* and Kunio YamaUCHI \\ Department of Agricultural Chemistry, The University of Tokyo, \\ Bunkyo-ku, Tokyo 113, Japan \\ Received February 28, 1978
}

\begin{abstract}
The protein which is antigenically equivalent to the soluble glycoprotein (SGP) isolated from milk fat globule membrane was immunologically found to be contained in whey protein. The identical antigeneicity between the SGP and an unknown protein component of whey was certified by double immunodiffusion and immunoelectrophoretic assays, using the antiserum of the SGP and its antiserum absorbed with whey protein, and using the whey protein fractions fractionated by gel filtration or ion exchange chromatography.

The concentration of this protein in whey (anti-SGP reacting protein) was estimated to be about $15 \%$ of total whey protein by simple radial immunodiffusion assay.

The major whey protein components, such as $\beta$-lactoglobulin, $\alpha$-lactalbumin, bovine serum albumin, and IgG-immunoglobulin were confirm $ə d$ to be not the anti-SGP reacting protein by the indirect elimination method. Anti-SGP reacting protein was found to be rich in the heat-stable protein fraction which corresponds to the so-called proteose-peptone fraction.
\end{abstract}

The soluble glycoprotein (SGP) prepared by delipidation of fat globule membrane of bovine milk is immunologically heterogeneous, ${ }^{1)}$ although it is apparently homogeneous by ordinary physical measurements. ${ }^{2}$

During further investigation on the immunological properties of the soluble glycoprotein fraction, we found that the major precipitate line of the soluble glycoprotein fraction disappreared when assayed by double immunodiffusion test between the antigen and the antiserum of the soluble glycoprotein absorbed with whey protein.

The present study was undertaken to ascertain the immunological identity of the unknown component(s) of whey to the soluble glycoprotein.

\section{MATERIALS AND METHODS}

Materials. Sephadex G-150, Bio Gel A-1.5 m and A-5 $\mathrm{m}$ (100 200 mesh) and DEAE-cellulose were purchased from Pharmacia Fine Chemicals (Uppsala,

* Present address; Faculty of Agriculture, Utsunomiya University, Utsunomiya 320 , Japan.
Sweden), Bio Rad Laboratories (Richmond, U.S.A.), and Seikagaku Kogyo Co. (Tokyo, Japan), respectively. Agar (Special Agar Novel) and complete Freund adjuvant were obtained from DIFCO Laboratories (Detroit, U.S.A.). Agarose was purchased from Nakarai Chemical Ltd. (Kyoto, Japan). Antiserum of bovine serum (rabbit) and of bovine serum albumin (rabbit) were obtained from Miles Laboratories, Inc. (Elkhart, U.S.A.). Carboxymethyl cellulose (CM 52) was purchased from Whatman Ltd. (Maidstone, Kent, England).

Preparation of soluble glycoprotein. The soluble glycoprotein was prepared by gel filtration on Bio Gel A-5m of the soluble apoprotein fraction which was obtained by delipidizing the low density fraction of milk fat globule membrane with a mixture of methanol and chloroform $(1: 2, \mathrm{v} / \mathrm{v})$, as described in the previous paper. ${ }^{2)}$

Preparation of whey protein. The pooled fresh bovine skimmilk was centrifuged for $60 \mathrm{~min}$ at 106,000 $\times g$ and at $15^{\circ} \mathrm{C}$. The supernatant was collected by a syringe, avoiding contamination of smaller fat globules in the top layer and of skimmilk membrane in the fluffy fraction as carefully as possible. The collected supernatant was then recentrifuged under the same conditions. The recovered supernatant was adjusted to pH 4.6 to remove the residual casein, dialyzed against deionized water at $4^{\circ} \mathrm{C}$, and freeze-dried. 
Preparation of heat-stable protein. The whey protein prepared as described above was dissolved in $0.15 \mathrm{M}$ sodium chloride, $\mathrm{pH} 7.0$, heated at $95^{\circ} \mathrm{C}$ for time as stated, and immediately cooled to $25^{\circ} \mathrm{C}$. The denatured protein was first removed by centrifugation for $20 \mathrm{~min}$ at $1000 \times \mathrm{g}$. The supernatant recovered was again centrifuged for $30 \mathrm{~min}$ at $40,000 \times g$ to remove precipitable protein and adjusted to $\mathrm{pH} 4.6$ with $0.01 \mathrm{~N}$ $\mathrm{HCl}$. The protein precipitated at $\mathrm{pH} 4.6$ was removed by centrifugation for $20 \mathrm{~min}$ at $40,000 \times g$. Finally the supernatant, a heat-stable protein fraction, was readjusted to $\mathrm{pH} c a .7 .5$ and was used for a simple radial immunodiffusion assay.

Gel filtration. Gel filtration of whey protein was performed on Sephadex G-150 $(2 \times 145 \mathrm{~cm})$ or Bio Gel A-1.5 m $(1.5 \times 96 \mathrm{~cm})$ equilibrated with $0.1 \mathrm{~m}$ Tris- $\mathrm{HCl}$ buffer, $\mathrm{pH} 8.0$, containing $0.1 \%$ sodium azide. Protein was eluted with the same buffer and absorbancy was scanned at $280 \mathrm{~nm}$. A flow rate was $2 \mathrm{ml}$ and $3 \mathrm{ml}$ per hour for Sephadex G-150 and Bio Gel A-1.5 m, respectively. The eluted fractions were dialyzed against distilled water and freeze-dried.

Ion exchange chromatography. DEAE-cellulose washed with acid and base was preequilibrated with $0.005 \mathrm{~m}$ Tris-phosphate buffer, $\mathrm{pH} 8.6$, degassed and poured into a column $(2.0 \times 15.5 \mathrm{~cm})$ with positive pressure. After equilibration with the starting buffer, whey protein (about $300 \mathrm{mg}$ ) was applied to the column. The elution was performed with a linear gradient of Tris-phosphate buffer, $\mathrm{pH} 8.6$ from $0.01 \mathrm{M}$ to $0.5 \mathrm{M}$. The concentration of protein was scanned at $280 \mathrm{~nm}$. The flow rate was $36 \mathrm{ml}$ per hour. The eluted fractions were dialyzed against distilled water and freezedried.

Immunological methods. Antisera to the soluble glycoprotein (anti-SGP) were prepared by immunizing rabbits with intradermal injection of the antigen in complete Freund's adjuvant at intervals of two weeks over a period of 4 to 5 months.

Immunoelectrophoresis was performed according to the micromethod of Scheidegger ${ }^{3)}$ with $1 \%$ agarose in $0.05 \mathrm{M}$ barbital buffer, $\mathrm{pH}$ 8.6. Electrophoresis was done in $0.025 \mathrm{M}$ barbital buffer, $\mathrm{pH} 8.6$, at a current of $6 \mathrm{~V}$ per $\mathrm{cm}^{4)}$

Ouchterlony double immunodiffusion was carried out in $1.0 \%$ agar in barbital buffer, $\mathrm{pH} 8.6$, containing $0.1 \%$ sodium azide. ${ }^{5)}$

Quantitative simple radial immunodiffusion was done following the procedure described by Heremans ${ }^{8)}$ in $1.5 \%$ agar in barbital buffer, $\mathrm{pH} 8.6$, containing $25 \%$ (v/v) antiserum. Diffusion was performed at $25^{\circ} \mathrm{C}$ for $92 \mathrm{hr}$. The unstatined plate was magnified on a comparator and the relative areas of the precipitate were given as grams of the paper weight. A standard curve was constructed using the soluble glycoprotein over the range of $11 \sim 110 \mu \mathrm{g}$ per $\mathrm{ml}$.

Precipitates were stained with Coomassie brilliant blue $\mathbf{R}-250 .{ }^{5)}$

Polyacrylamide gel electrophoresis. Disc electrophoresis was performed by the procedure of Davis. ${ }^{\text {T) }}$ Acrylamide concentration of the separation gel was $9 \%$ and the ratio of acrylamide to methylenebisacrylamide was kept at 37: 1 in weight. Protein was stained with Coomassie brilliant blue R-250 as described by Weber and Osborn. ${ }^{8)}$ Glycoprotein was stained with the periodic acid-Schiff reagent as described by Neville and Glossmann. ${ }^{\text {) }}$

Protein determination. The protein concentration was measured by Lowry procedure. ${ }^{10)}$ Bovine serum albumin was used as the standard.

\section{RESULTS}

\section{Antigenic identity}

On double immunodiffusion assay, whey protein formed a broad precipitate line with anti-SGP, while the soluble glycoprotein also formed one major and two minor precipitate lines. The major lines of whey protein and the soluble glycoprotein were completely fused

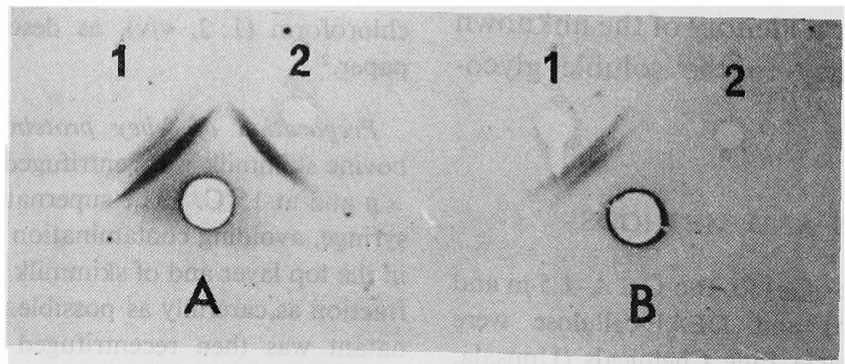

Fig. 1. Comparison of Double Immunodiffusion Analysis of Whey Protein (2) and the Soluble Glycoprotein (1) Using the Antiserum of the Soluble Glycoprotein (A) and the Antiserum Absorbed with Whey Protein (B). 
Table I. The Concentration of the Anti-SGP Reacting Protern

Anti-SGP reacting protein was determined by simple radial immunodiffusion assay. The soluble glycoprotein was used for construction of standard curve. n.d., not detected profoundly; n.e., not estimated.

\begin{tabular}{lcc}
\hline & $\begin{array}{c}\text { Fraction } \\
\text { obtained by } \\
\text { gel filtration }\end{array}$ & $\begin{array}{c}\text { Concentration } \\
\text { of anti-SGP } \\
\text { reacting protein }\end{array}$ \\
\hline $\begin{array}{l}\text { Total whey protein } \\
\text { Sephadex G-150 }\end{array}$ & $\begin{array}{c}14 \sim 16 \% \\
\text { fraction 1 }\end{array}$ & 45 \\
& fraction 2 & 21 \\
fraction 3 & n.d. \\
& fraction 4 & n.d. \\
fraction 5 & n.d. \\
& fraction 1 & n.e. \\
& fraction 2 & 18 \\
& fraction 3 & n.d. \\
fraction 4 & n.d. \\
Heat-stable protein fraction & $39 \sim 60$ \\
\hline
\end{tabular}

and the arc formed by the fusion is almost symmetrical (Fig. 1-A). The reaction indicates the presence of identical antigenic determinants in the compared reactants.

On the other hand, against anti-SGP absorbed with an excessive amounts of whey protein both the precipitate line of whey protein and the major line of the soluble glycoprotein disappeared (Fig. 1-B). Minor lines of the soluble glycoprotein remained. This type of reaction also indicates that both proteins which disappeared were antigenically equivalent each other and the proteins corresponding to the minor precipitate lines of the soluble glycoprotein were not contained in whey protein.

The concentration of the protein which reacted with anti-SGP was estimated to be about $15 \%$ in whey protein (Table I).

In addition, the soluble glycoprotein did not react with the anti-bovine serum under conditions used here. It seems that the soluble glycoprotein and the whey protein component(s) which reacts with anti-SGP do not originate from bovine serum protein. The unidentified component of whey protein which reacted with anti-SGP was hereafter termed anti-SGP reacting protein.

Fractionation of whey protein by gel filtration In order to ascertain the authentic presence of the anti-SGP reacting protein, the total whey protein was fractionated by gel filtration. The

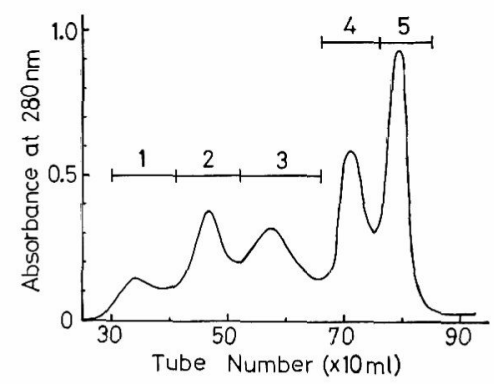

FIG. 2. Elution Pattern of Whey Protein from a Sephadex G-150.

The total whey protein $(60 \mathrm{mg})$ was eluted with Tris$\mathrm{HCl}$ buffer, $\mathrm{pH} 8.0$, containing $0.1 \%$ sodium azide.

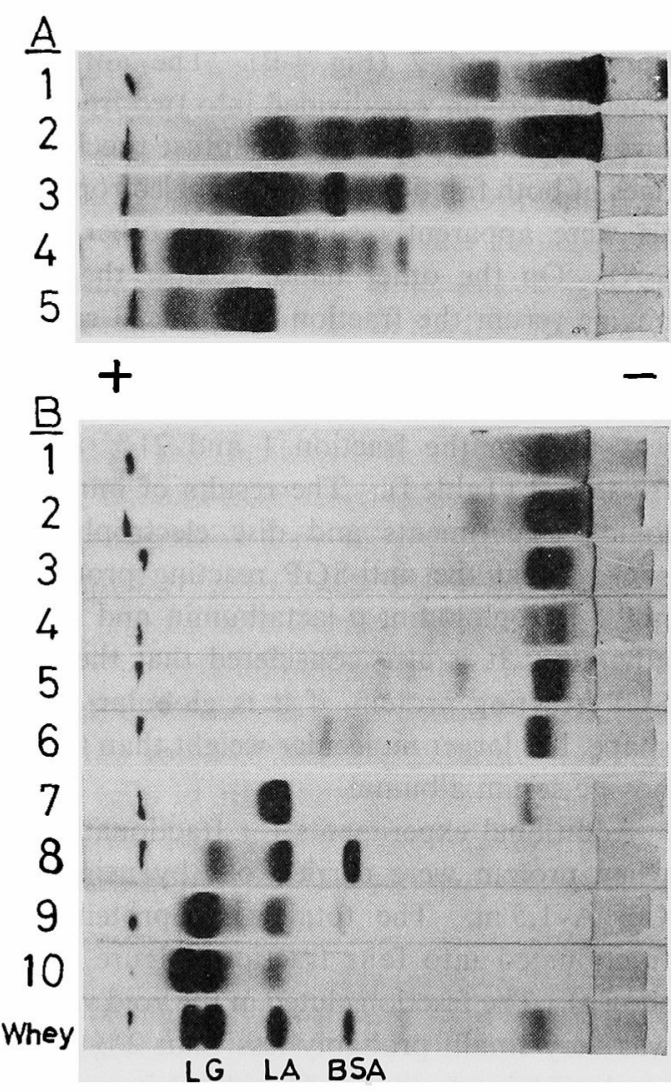

FIG. 3. Disc Electrophoretic Patterns of Fractions Eluted from a Sephadex G-150 (A) and DEAECellulose (B) of Whey Protein.

Numerals in the figure indicate the order of the fraction shown in Fig. 2 for Sephadex G-150 or in Fig. 6 for DEAE-cellulose. LG, $\beta$-lactoglobulin; LA, $\alpha$-lactalbumin; BSA, bovine serum albumin. 
obtained fractions were immunochemically studied.

Whey protein was fractionated into five fractions on Sephadex G-150 (Fig. 2) and each fraction was analyzed by disc electrophoresis (Fig. 3-A). Serum albumin, $\beta$-lactoglobulin and $\alpha$-lactalbumin were found in the fraction 3,4 , and 5 , respectively, while immunoglobulins and other minor protein components were eluted in the fraction 1 and 2. The anti-SGP reacting protein was found in the fraction 1 and 2 on double immunodiffusion (Fig. 4-A) and immunoelectrophoresis (Fig. 5-A). The lines of the fraction 1, 2 and total whey protein were completely fused (Fig. 4-A). Against anti-SGP previously absorbed with whey protein, no precipitate line was detected in the fraction 1 and 2 (Fig. 4-B). The anti-SGP reacting protein was divided into two fractions on gel filtration but long and diffuse precipitate lines of both fractions on immunoelectrophoresis were apparently similar each other (Fig. 5-A). On the other hand, against the antibovine serum the fraction 1,2 , and 3 reacted but the fraction 4 and 5 did not (Fig. 4-C). The content of the anti-SGP reacting protein was $45 \%$ in the fraction 1 and $21 \%$ in the fraction 2 (Table I). The results of immunological experiments and disc electrophoresis suggest that the anti-SGP reacting protein is not $\beta$-lactoglobulin, $\alpha$-lactalbumin and serum albumin. It is also considered that the antiSGP reacting protein, if it is globular in the shape, has larger molecular weight than that of bovine serum albumin.

Additional experiments for fractionation of whey protein were carried out by using Bio Gel A-1.5 m. The total whey protein was fractionated into four fractions (figure is not shown). The fraction eluted at the void volume was very small, probably less than $2 \%$ of the total protein charged. Therefore, it was concluded that the whey protein used in this study was scarecely contaminated with the fragments of fat globule membrane and small fat globules which were considered to be eluted at the void volume. Of the other three fractions, the antiSGP reacting protein was found only in the fraction 2 , in which serum albumin was eluted (Table I). $\quad \beta$-Lactoglobulin and $\alpha$-lactalbumin were also confirmed to have no relation to this antigenecity.

\section{Fractionation of whey protein by ion exchange chromatography}

In order to obtain further information on
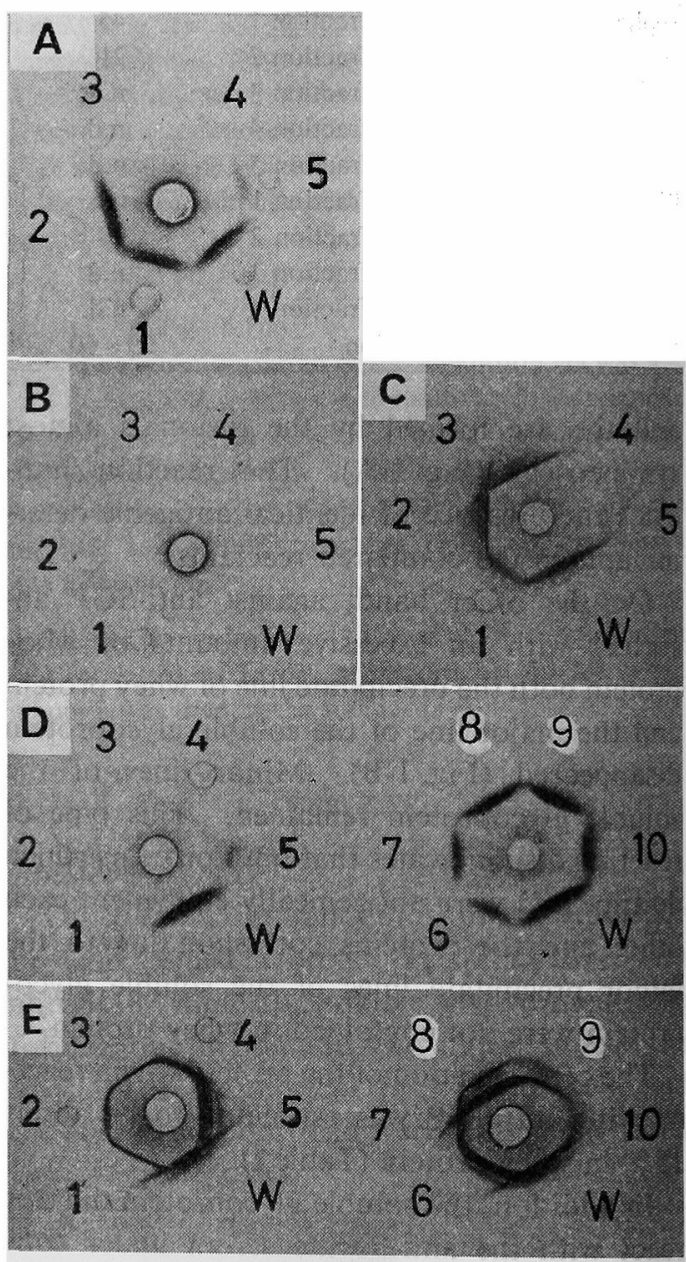

FIG. 4. Comparison of Double Immunodiffusion Assays of Fractions Obtained by Gel Filtration on a Sephadex G-150 (A, B and C) and by Ion Exchange Chromatography on DEAE-Cellulose (D and E).

$A$ and $\mathrm{D}$ were assayed against the antiserum of the soluble glycoprotein, B against the anti-soluble glycoprotein absorbed with whey protein, and $\mathrm{C}$ and $\mathrm{E}$ against the anti-bovine serum. Numerals in the figure indicate the order of the fraction shown in Fig. 2 for Sephadex G-150 or in Fig. 6 for DEAEcellulose. W; total whey protein. 

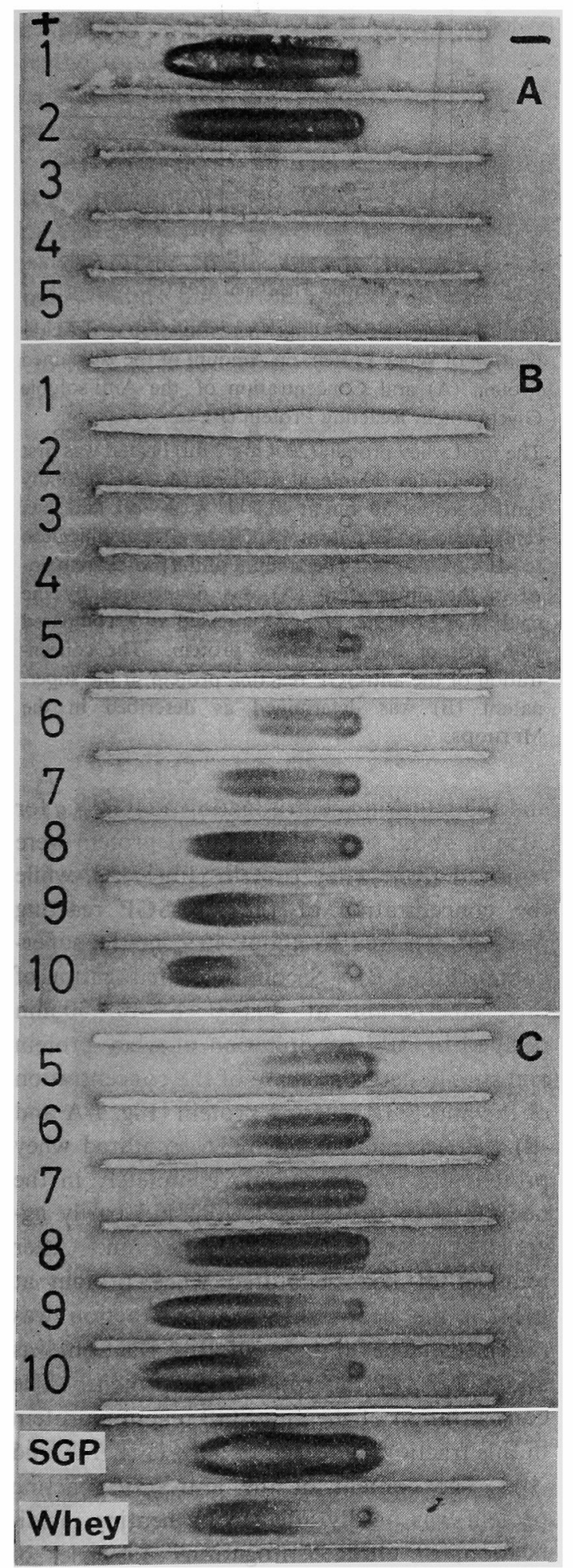

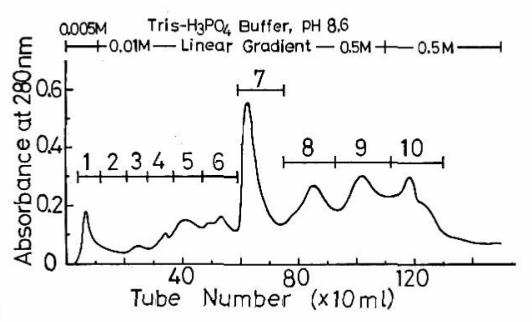

FIG. 6. Elution Pattern of Whey Protein on DEAECellulose Chromatography.

The total whey protein $(300 \mathrm{mg})$ was eluted with Trisphosphate buffer, $\mathrm{pH} 8.6$, as indicated in the figure. A linear gradient was obtained by using $0.01 \mathrm{~m}$ Trisphosphate buffer, $\mathrm{pH} 8.6$, as a starting buffer and $0.5 \mathrm{M}$ Tris-phosphate buffer, $\mathrm{pH}$ 8.6, as a limited buffer.

the properties of the anti-SGP reacting protein and to isolate it, the total whey protein was subjected to ion exchange chromatography on DEAE-cellulose. A typical elution pattern is shown in Fig. 6 . Whey protein was divided into ten fractions. Disc electrophoretic patterns are shown in Fig. 3-B. Protein components having larger molecular weight and being minor were eluted in the fractions 1 to 6 , while major whey proteins such as $\beta$-lactoglobulin, $\alpha$-lactalbumin and serum albumin were eluted in the fractions 6 to 10 . Immunologically, the anti-SGP reacting protein was found in the fractions 3 to 10 , contrary to our expectation (Fig. 4-D and Fig. 5-B). All fractions reacted with the anti-bovine serum (Fig. 4-E). IgG-immunoglobulin unbound to DEAE-cellulose was suggested to be not related with the anti-SGP reacting protein.

As seen in the immunoelectrophoretic patterns, the length of the precipitation lines of the anti-SGP reacting protein on immuno-

FIG. 5. Comparison of Immunoelectrophoretic Patterns of Fractions Obtained by Gel Filtration on a Sephadex G-150 (A) and by Ion Exchange Chromatography on DEAE-Cellulose ( $\mathrm{B}$ and $\mathrm{C}$ ) Using the Antiserum to the Soluble Glycoprotein.

Each fraction of (C) corresponds to that of (B) but was heated for $30 \mathrm{~min}$ at $90^{\circ} \mathrm{C}$ and centrifuged for $30 \mathrm{~min}$ at $40,000 \times g$ without acidification. Numerals in the figure indicate the order of the fraction shown in Fig. 2 for Sephadex G-150 or in Fig. 6 for DEAEcellulose. SGP; soluble glycoprotein. 
electrophoresis increased in the order of the fraction eluted through DEAE-cellulose (Fig. 5-B). Such behavior suggests that the antiSGP reacting protein is apparently heterogeneous. However, the lines of the fractions 5 to 10 and of whey protein were completely fused on double immunodiffusion (Fig. 4-D). The result shows that the anti-SGP reacting protein found in each fraction has identical antigenecity, even if it has heterogeneous property. In addition, a different type of precipitation line was newly detected in the fraction 4 and 5 on both immunodiffusion and immunoelectrophoretic assay (Fig. 4-D and Fig. 5-B). This line was not fused with the line of whey protein or that of other fractions. The component corresponding to this line was probably concentrated in the fraction 4 and 5 through the fractionation, although it was not detected in the total whey.

Furthermore, the total whey protein was chromatographed on DEAE-cellulose with a linear gradient from $0.005 \mathrm{M}$ to $0.5 \mathrm{M}$ potassium phosphate buffer, $\mathrm{pH} 6.0$ or on carboxymethyl cellulose with a linear gradient from $0.005 \mathrm{M}$ to $0.5 \mathrm{M}$ acetate buffer, $\mathrm{pH} 4.6$ (data is not shown). The results indicated that the antiSGP reacting protein was separated into several fractions, as found on DEAE-cellulose, Trisphosphate buffer, pH 8.6.

\section{Relation of anti-SGP reacting protein with heat- stable protein}

The above results showed that the major proteins of whey such as $\beta$-lactoglobulin, $\alpha$-lactalbumin and serum albumin were eliminated from an objective protein corresponding to the anti-SGP reacting protein. We aimed at the concentration of the anti-SGP reacting protein in whey and it was found that the protein was present in the heat-stable protein fraction, the so-called proteose-peptone fraction.

Relation between the concentrations of the anti-SGP reacting protein and of the heatstable protein was investigated by three successive precipitations of denatured whey protein. The results are shown in Fig. 7. First, by heating whey protein at $95^{\circ} \mathrm{C}$ for $5 \sim 60 \mathrm{~min}$

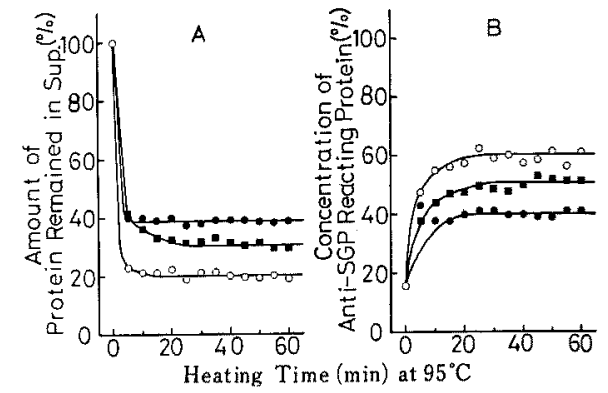

FIG. 7. Effect of Heating, Centrifugation and Acidification of Whey Protein on Amount of the Remained Protein (A) and Concentration of the Anti-soluble Glycoprotein Reacting Protein (B).

The total whey protein $(20.4 \mathrm{mg} / 2 \mathrm{ml})$ heated was first centrifuged for $30 \mathrm{~min}$ at $1000 \times g(-\mathbf{0})$, secondly centrifuged for $30 \mathrm{~min}$ at $40,000 \times g$ (-ㅜ), and then centrifuged for $20 \mathrm{~min}$ at $40,000 \times g$ after acidification to $\mathrm{pH} 4.6(\mathrm{O}-\mathrm{O})$. The amount of the protein remained in the supernatant (A) was determined by the method of Lowry et al. and expressed as \% compared with that of the total whey protein. The concentration of the anti-SGP reacting protein in the supernatant (B) was determined as described in the Methods.

and the following centrifugation at $1000 \times g$ for $30 \mathrm{~min}$, about $60 \%$ of denatured protein were removed from whey protein (Fig. 7-A), while the concentration of the anti-SGP reacting protein increased to about $40 \%$ in the supernatant (Fig. 7-B). Secondly, centrifugation of this supernatant at $40,000 \times g$ for $30 \mathrm{~min}$ resulted in $70 \%$ precipitation of whey protein and simultaneous increase of the concentration of the anti-SGP reacting protein (Fig. 7-A and -B). It was shown that heat-denatured whey protein did not precipitate completely in the neutral whey protein solution, but easily aggregated by the following acidification. After removal of heat-denatured whey protein at $\mathrm{pH} 4.6$, the heat-stable protein fraction was obtained. The amount of this fraction was about $20 \%$ of the total whey protein. The concentration of the anti-SGP reacting protein in this fraction increased to $60 \%$ (Fig. 7-A and -B). The content of the anti-SGP reacting protein was hardly affected by heating, acidification, or ultracentrifugation. In series of these experiments, the loss of the anti-SGP 
reacting protein was only about $5 \%$. The concentration of the heat-stable protein fraction in the total whey protein was almost similar to that of the proteose-peptone fraction as reported by other investigators. ${ }^{11)}$

The heat-stable protein fraction obtained from the total whey protein heated for 30 $\min$ at $95^{\circ} \mathrm{C}$ was analyzed on disc electrophoresis (Fig. 8-A). It was separated into many bands under the conditions used here. Its electrophoretic pattern was somewhat different from that reported by NG et al. ${ }^{12)}$ However, the regions indicated with Roman numerals in Fig. 8-A-2 seem to correspond to components 3,5 and 8 of the proteose-peptone fraction obtained by NG et al. ${ }^{12)}$ Fractionation of components 3,5 and 8 and their heterogeneities will be reported elsewhere. Using the anti-SGP, it was shown that the heat-stable protein, the soluble glycoprotein, and the total whey protein were antigenically identical each
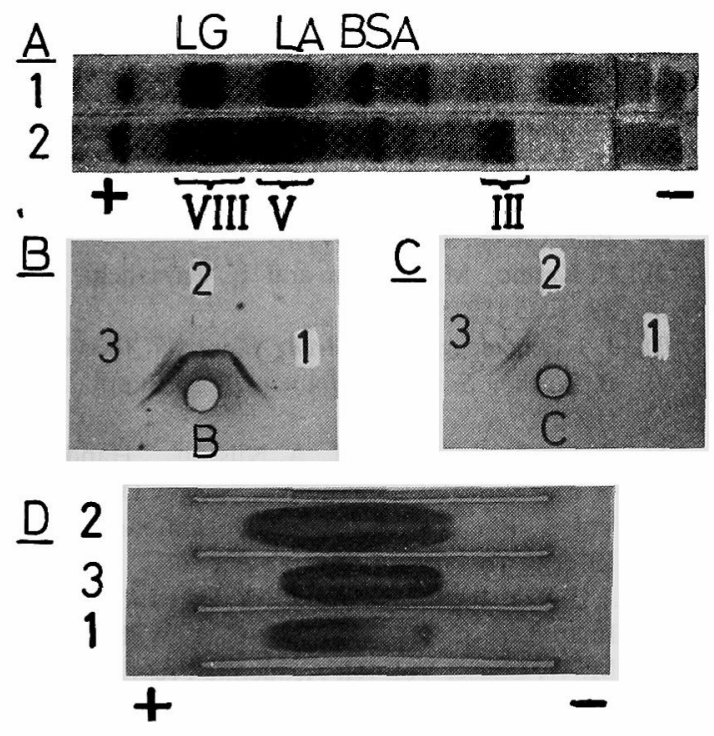

FIG. 8. Analyses of the Heat-stable Protein Fraction on Disc Electrophoresis (A), Double Immunodiffusion (B and C), and Immunoelectrophoresis (D).

Immunodiffusion was performed against the antiserum of the soluble glycoprotein (B and D) and its antiserum absorbed with whey protein $(C)$. 1, total whey protein; 2 , heat-stable protein fraction; 3 , soluble glycoprotein; BSA, serum albumin; LG, $\beta$-lactoglobulin; LA, $\alpha$-lactalbumin. other (Fig. 8-B). The heat-stable protein fraction did not react with the antiserum of the soluble glycoprotein absorbed with whey protein (Fig. 8-C). The precipitation line of the heat-stable protein fraction on immunoelectrophoresis was diffuse and long (Fig. 8-D). The anti-SGP reacting protein in the heat-stable protein fraction had the properties of polydispersity as well as the soluble glycoprotein. ${ }^{1}{ }^{1}$ This observation was consistent with the heterogeneous behavior of the anti-SGP reacting protein found on ion exchange chromatography.

The fractions obtained by ion exchange chromatography of whey protein as described above were heated to $95^{\circ} \mathrm{C}$ for $30 \mathrm{~min}$ and the heatstable protein in the respective fraction was recovered. Immunoelectrophoretic patterns of these fractions were shown to be almost similar before and after heating, except that more dense lines were observed after heating (Fig. 5-C). These lines were antigenically identical each other. A minor precipitation line in the fraction 5 was also heat-stable.

It was thus demonstrated that the protein in whey which is antigenically identical to the soluble glycoprotein occurrs in the so-called proteose-peptone fraction.

\section{DISCUSSION}

It was found that the protein which is antigenically identical to the soluble glycoprotein of milk fat globule membrane is contained in whey.

The soluble glycoprotein was isolated from the soluble apoprotein fraction of the delipidized milk fat globule membrane by many investigators. ${ }^{1,13,14,15)}$ The physicochemical properties of their preparations, however, are not always concorded. The soluble glycoprotein isolated by us ${ }^{1)}$ was characteristically richer in total carbohydrate $(30 \%)$ compared with the preparations isolated by other investigators. Furthermore, our soluble glycoprotein consisted of eight polypeptides (seven of them were glycopeptides) which had relatively low molecular weights. ${ }^{16)}$

Jackson et al. isolated the soluble glyco- 
protein (they called it mucoprotein) and reported its immunological properties. ${ }^{14,17}$ ) They claimed that their mucoprotein preparation was homogeneous when analyzed not only by ultracentrifugation and free-boundary electrophoresis, but also by immunoelectrophoresis using the antiserum of the mucoprotein $a b$ sorbed with whey protein. ${ }^{17}$ ) Our present finding does not agree with their results. The difference may be explained by our previous finding that different preparation procedures including the method used by Jackson et al. ${ }^{14}$ give rise to the soluble glycoprotein fraction which has different physicochemical properties and polypeptide compositions. ${ }^{18}$ Our preparation was composed of the polypeptides with relatively low molecular weights, PAS-I to -VII and CB-III, which were not present in the insoluble apoprotein fraction, ${ }^{16}$ ) while the preparation obtained by the method of Jackson et al. ${ }^{14)}$ contained several polypeptides present in the insoluble apoprotein fraction in addition to the polypeptides of our preparation. Speculating the fact that their mucoprotein preparation was heterogeneous against the antiserum of the mucoprotein but homogeneous against its antiserum absorbed with whey protein, ${ }^{17}$ ) it is considered that the protein which disappeared against the latter antiserum might be a part of the soluble glycoprotein consisting of the glycopeptides of low molecular weights which were similar to our preparation. ${ }^{18}$ ) On the other hand, the protein which remained as only one precipitate line is likely to be the protein composed of the polypeptide found mostly in the insoluble apoprotein fraction by $u^{18)}$ and absent in whey protein. The protein which disappeared from the mucoprotein preparation of Coulson and Jackson by immunological absorption ${ }^{17 /}$ may correspond to our anti-SGP reacting protein. Coulson and Jackson $^{17)}$ considered the above protein as a contaminant from whey but we consider that the anti-SGP reacting protein is indigenously present in the soluble glycoprotein of milk fat globule membrane.

Our results indicated that the anti-SGP reacting protein in whey was present in the heat-stable protein fraction, the so-called proteose-peptone fraction. It is known that the proteose-peptone faction is not secondary degradated protein but naturally occurring protein in milk. ${ }^{11,12,197}$ Brunner and Thompson ${ }^{20}$ compared the physicochemical properties of the soluble glycoprotein fraction of milk fat globule membrane with those of the proteosepeptone fraction. However, they could not find the similarity between these fractions. The detailed studies on the antigenic relationship between the soluble glycoprotein and each component of the proteose-peptone fraction will be described elsewhere.

It may be interesting to find out why the protein which is antigenically equivalent to both the soluble glycoprotein and the anti-SGP reacting protein is distributed in the milk fat globule membrane and whey, and whether the protein is incorporated into the fat globule membrane before or after milk secretion, These problems are remained for further study.

Acknowledgement. We thank Dr. M. Shimizu for preparation of the soluble glycoprotein.

\section{REFERENCES}

1) C. Kanno, M. Shimizu and K. Yamauchi, Agric. Biol. Chem., 41, 83 (1977).

2) C. Kanno, M. Shimizu and K. Yamauchi, ibid., 39, 1835 (1975).

3) J. J. Scheidegger, Int. Arch. Allergy, 7, 103 (1955).

4) B. Weeke, Scand. J. Immunol., 2, Suppl. 1, 15 (1973).

5) O. Ouchterlony and L. A. Nilsson, "Handbook of Experimental Immunology," ed. by D.M. Weir, Vol. 1, Blackwell Scientific Publications, Oxford, 1973, p. 19.

6) J. F. Heremans, "Methods in Immunology and Immunochemistry," ed. by C. A. Williams and M. W. Chase, Vol. III, Academic Press Inc., New York and London, 1971, p. 213.

7) B. J. Davis, Ann. N. Y. Acad. Sci., 121, 404 (1964).

8) K. Weber and M. Osborn, J. Biol. Chem., 244, 4406 (1969).

9) D. M. Neville, Jr. and H. Glossmann, "Methods in Enzymology," ed. by S. Fleischer and L. Packer, Vol. XXXII, Academic Press Inc., New York and London, 1974, p. 92.

10) O. H. Lowry, N. J. Rosebrough, A. L. Farr and R. J. Randall, J. Biol. Chem., 193, 265 (1951).

11) R. McL. Whitney, J. R. Brunner, K. E. Ebner, 
H. M. Farrell, Jr., R. V. Josephson, C. V. Morr and H. E. Swasgodd, J. Dairy, Sci., 59, 795 (1976).

12) W. C. NG, J. R. Brunner and K. C. Rhee, ibid., 53, 987 (1970).

13) C. T. H. Herald and J. R. Brunner, ibid., 40, 948 (1957).

14) R. H. Jackson, E. J. Coulson and W. R. Clark, Arch. Biochem. Biophys., 97, 373 (1962).

15) F.C. Swope, K.C. Rhee and J.R. Brunner, Milchwissenschaft, 23, 744 (1968).
16) M. Shimizu, C. Kanno and K. Yamauchi, Agric. Biol. Chem., 40, 1711 (1976).

17) E. J. Coulson and R. H. Jackson, Arch. Biochem. Biophys., 97, 378 (1962).

18) K. Yamauchi, M. Shimizu and C. Kanno, J. Dairy Sci., 61, 688 (1978).

19) M. L. Gloves, ibid., 52, 1155 (1969).

20) J. R. Brunner and M. P. Thompson, ibid., 44, 1224 (1961). 